\title{
Peruvian Antiquities and the Collecting of Cultural Goods
}

Terrence H. Witkowski

California State University, Long Beach

Follow this and additional works at: https://digitalcommons.uri.edu/mgdr

Part of the Archaeological Anthropology Commons, Business Law, Public Responsibility, and Ethics Commons, History of Art, Architecture, and Archaeology Commons, and the Marketing Commons

\section{Recommended Citation}

Witkowski, Terrence H. (2017) "Peruvian Antiquities and the Collecting of Cultural Goods," Markets, Globalization \& Development Review. Vol. 2: No. 4, Article 3.

DOI: 10.23860/MGDR-2017-02-04-03

Available at: https://digitalcommons.uri.edu/mgdr/vol2/iss4/3

This Article is brought to you for free and open access by DigitalCommons@URI. It has been accepted for inclusion in Markets, Globalization \& Development Review by an authorized editor of DigitalCommons@URI. For more information, please contact digitalcommons-group@uri.edu. 


\section{Peruvian Antiquities and the Collecting of Cultural Goods}

\section{Markets, Globalization \& Development Review}
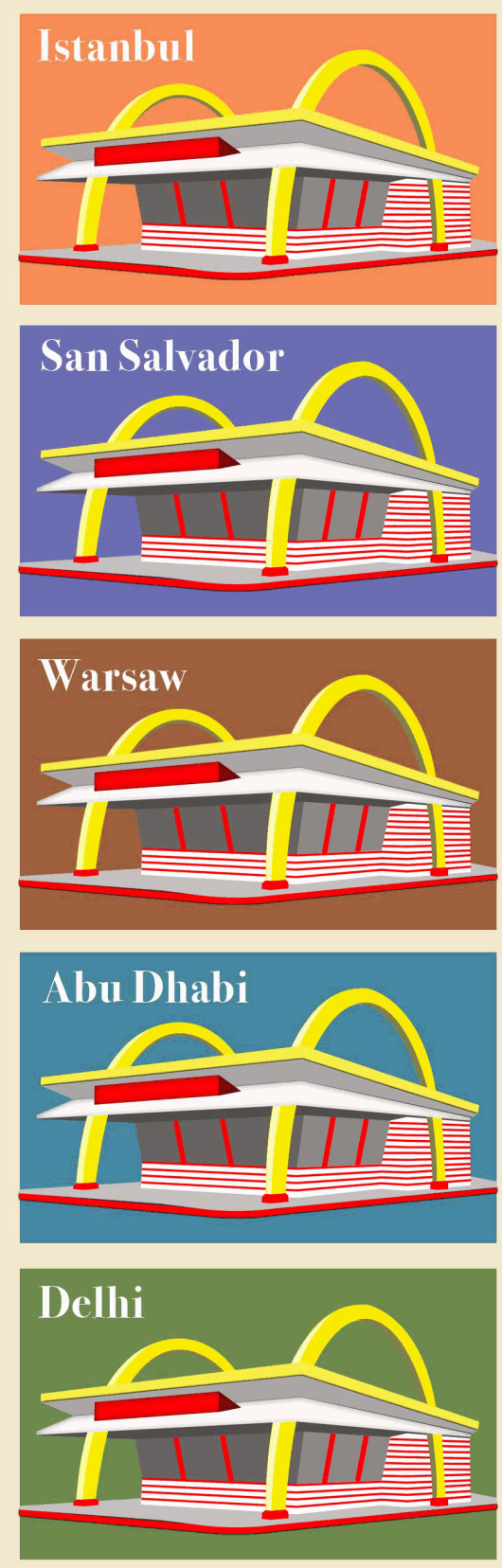
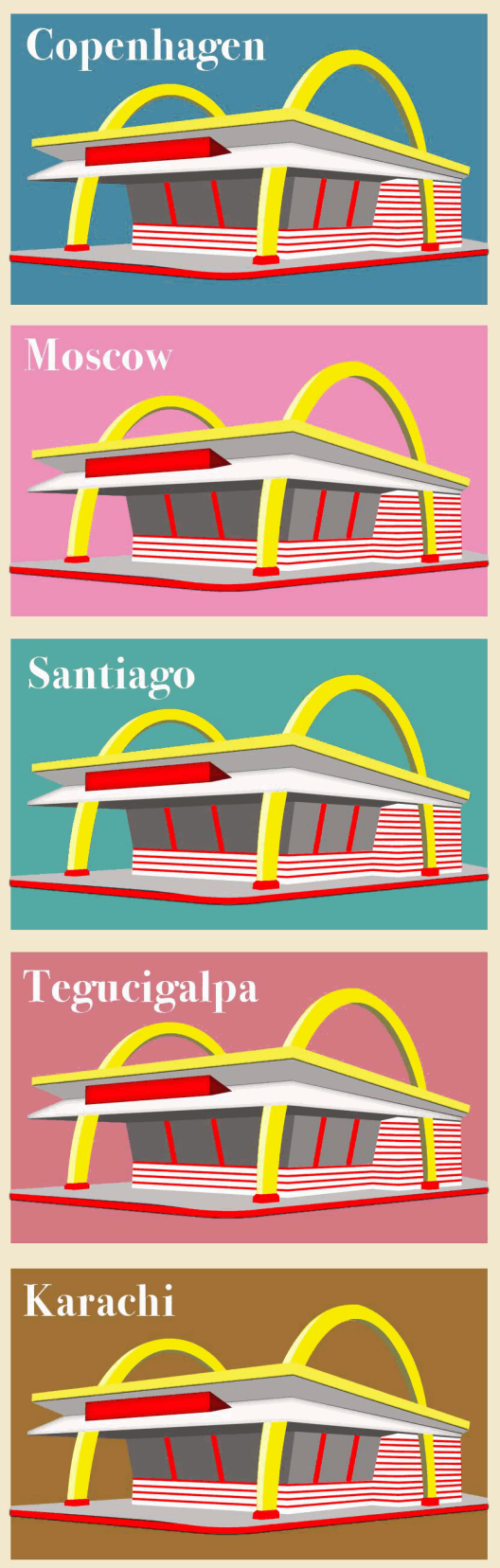
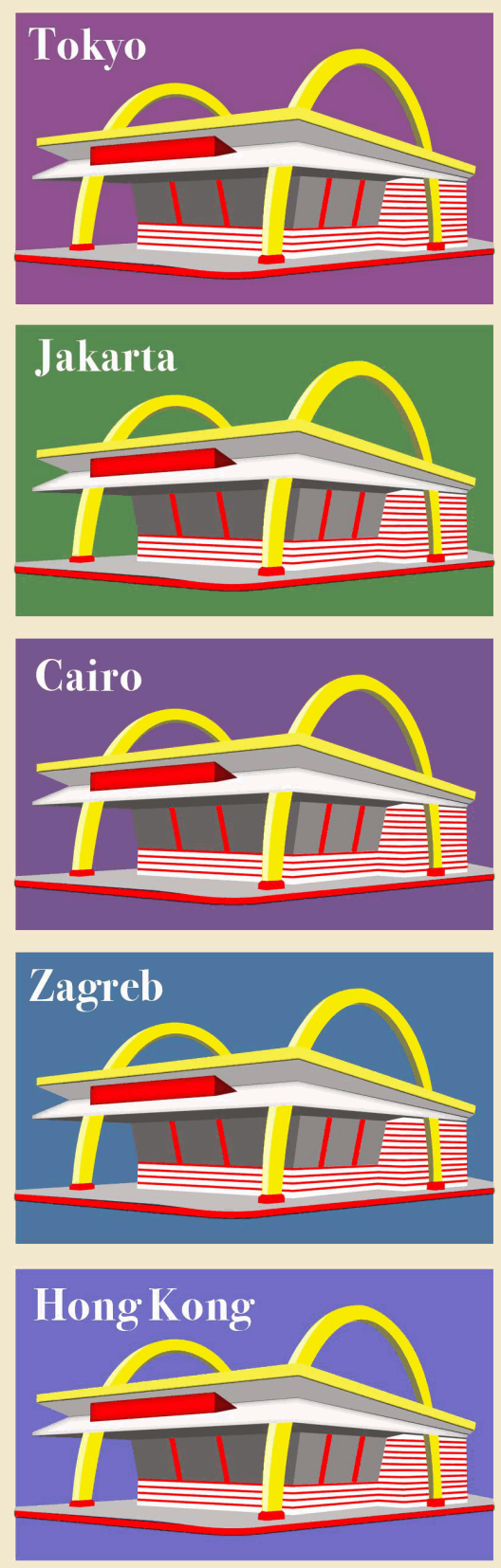

This article is available in Markets, Globalization \& Development Review: https://digitalcommons.uri.edu/mgdr/vol2/ 


\section{Peruvian Antiquities and the Collecting of Cultural Goods}

\section{Introduction}

The global antiquities market - the buying and selling of art, artifacts, and architecture from the ancient civilizations of Egypt and the Middle East, the Greek and Roman worlds, India, China, Southeast Asia, Australasia, the Americas, and Africa - has had quite a long history. The ancient Romans, for example, collected artifacts produced earlier by the Greeks. In Asia, Chinese in the Tang Dynasty (618-907) acquired relics from India and their descendants in the Song Dynasty (960-1279) unearthed ancient Chinese bronzes and other objects (Belk 1995). Centuries later, when Roman sites were discovered in Europe circa 1450-1550, collector demand for excavated items was brisk and dealers profited. Strong interest in antiquities continued into the early modern period and later with perhaps the greatest, if not most controversial, collecting coup of all time being Lord Elgin's removal of marbles from the frieze of the Parthenon, along with other architectural members from the Acropolis, between 1801 and 1812. The cost of this massive operation was considerable and Elgin suffered a financial loss when he sold the assemblage to the British Museum in 1816.

The collecting of antiquities by private individuals and institutions has stimulated much exploration, scholarly research, and conservation. Museums have made antiquities available to a broad audience that would never have had the chance of seeing them in situ. Collecting has thus benefited humanity beyond just those involved in the chase. Yet, the collectors market for antiquities also has had serious negative consequences for recovering and preserving cultural heritage in source countries (Atwood 2004; Borodkin 1995; Gerstenblith 2007; Merryman 1986, 2005; Szopa 2004). As Fay (2011, p. 450) succinctly put it, by "purchasing artifacts with little or no provenance information, collectors wittingly or unwittingly enable looted artifacts to enter the marketplace." To supply the international market, archaeological sites have been pillaged and around the world cultural information has been destroyed (Atwood 2004, 2009; Brodie 2011). Then, flouting national laws and international conventions, valuable ancient works of art and culture have been trafficked across the borders of both rich and poor countries and especially in recent years from conflict zones such as Afghanistan, Iraq, Mali, and Syria (Cotter 2012; Myers 2010). In 2009, for example, more than 1500 stolen Afghan artifacts, confiscated at London's Heathrow 
Airport over a six-year period, were sent back to the National Museum in Kabul (Peters 2009). Between 2006 and 2010, major American museums including the Getty in Los Angeles, the Metropolitan Museum of Art in New York, the Boston Museum of Fine Arts, the Cleveland Museum of Art, and the Princeton University Art Museum repatriated important antiquities to Italy because evidence showed they were probably removed illegally (Felch and Frammolino 2011).

This article describes the market for Peruvian antiquities - here defined as the artifacts originally created by the country's many important pre-Conquest civilizations - and then focuses on the consequences of this collecting. In response to both local and international collector demand stretching back into the nineteenth century, a great number of valuable objects have been removed from structures and burials sites carelessly and without scientific documentation. Many of these items left the country for private collections and museums in Europe and North America, among other destinations. In the process, cultural information and aesthetic pleasures have been gained, but much more could have been learned had their excavation been better documented. Peru is a good source country for studying antiquities markets and the collecting of cultural goods. Peru boasts a very rich history and great archaeological wealth often found within spectacular Andean settings. The brutal Spanish conquest and population collapse of the 1500 s, the nearly three centuries of colonial rule by the Viceroyalty of Peru, and the successful War of Independence in the early 1800 s provide a highly charged historical backdrop for arguments over the ownership and protection of Peruvian cultural heritage and property

Two general questions guide this investigation: 1) what has been the aggregate impact over time of antiquities collecting on Peru's cultural heritage and 2) what should be the responsibilities of private and institutional collectors of Peruvian antiquities? These questions and the research they invite are relevant to several disciplines including archaeology, art history, international law, material culture, and museum studies. The collecting of Peruvian cultural goods also should be of interest to the field of macromarketing whose domain spans market formation and history, ethics and distributive justice, and the welfare of developing countries. How marketing systems affect and are affected by society constitute central issues in the macromarketing discipline (Hunt 1981; Layton 2007). Markets, like those for antiquities, can be legal, grey, or black (Layton 2015). However, the macromarketing literature has not seriously addressed antiquity markets and their societal consequences. 
The next section briefly reviews Peru's pre-Columbian history, as well as the history of collecting, preserving, and displaying objects from this era. Some historical and material culture grounding is necessary to understand why and how Peruvian art, artifacts, and architecture have attracted collectors and connected them with Peru's past. As will be shown, visual and sensory appeal along with romantic imagination clearly has helped to drive demand for Peruvian antiquities. Then, the analysis turns to an investigation of today's market for Peruvian antiquities. This section discusses antiquity market concepts and processes, considers the impact of online selling, and reports findings from preliminary research on contemporary eBay sales of pre-Columbian Peruvian antiquities. After looking into current market conduct, the article considers implications of the market and collecting for the preservation of Peru's cultural heritage. This section examines points of view of market participants and critical publics and considers the responsibilities of collectors and strategies for mitigating market externalities. The conclusion provides a recap and suggests further research opportunities.

Given the many ethical ramifications of collecting cultural goods, investigators should disclose potential conflict of interest. I do not collect Peruvian or any other Latin American antiquities or Spanish colonial period art and artifacts. I have for many years collected Americana and some Asian and European antiques and thus have gained market experience and self-awareness of acquisitive impulses. An interest in antiquities surfaced in 2005 when I started purchasing ceramic bowls, dishes, and jars from the ca. 1500 "Hoi An" shipwreck salvaged in 1996 (Pope 2007). The government of Vietnam sold thousands of duplicate items through public auctions. However, I also bought four undocumented Vietnamese ceramic bowls from the same era from dealers in Hanoi and Singapore. Hmong and other hill tribes probably excavated these pieces from gravesites in western Thailand. Hundreds of thousands of such pieces came to market in the 1980s (Brown 1988). In 2011, I acquired via eBay a seven-inch Chinese terra cotta funerary attendant statue purportedly circa $900 \mathrm{CE}$. Such pieces are relatively common on the collectors market, but this one got me reading and thinking about the problems of looting and loss of cultural heritage. With heightened ethical awareness, I backed away from the antiquities market.

\section{Pre-Columbian Peru and the Collecting of Its Artifacts}

Spelling of Peruvian cultural and place names varies: Inca and Inka; Cuzco, Cusco, and Qosqo; Machu Picchu and Machu Pikchu. This article uses the more traditional English language spellings of Inca, Cuzco, and 
Machu Picchu. The term "Indian" is used rather than "Native American" since as Mann (2005) points out this is how indigenous people usually refer to themselves. For dating purposes, BCE (Before Common Era) and $\mathrm{CE}$ (Common Era) are used instead of the equivalent, but religiously charged $\mathrm{BC}$ and $\mathrm{AD}$.

\section{Pre-Columbian Civilizations of Peru}

Peru is a medium-sized yet very biodiverse country comprised of three climate zones. Tropical forests cover the low-lying eastern $60 \%$ of the country, which is part of the Amazon basin. The Andean highlands run down the center of the country. Microclimates abound, but in general mountain rain forests dominate the eastern slopes and grasses and scrub characterize the valleys on the western side. The narrow Pacific coastal zone ranges from dry tropical savannah in the north to subtropical desert and scrub in the south. Lying in the arid rain shadow of the Andes, this region also feels the influence of the cold Humboldt Current in the Pacific Ocean, which keeps places like Lima cooler than expected given their tropical latitudes.

Although evidence of the earliest human habitation of Peru is sparse and sometimes disputed, nomadic hunter-gatherers appear to have migrated down the coastal littoral a good 15,000 years ago and then headed toward upland areas such as the Pikimachay site in the Ayacucho Valley half way between present day Lima and Cuzco (Dobyns and Doughty 1976; Mann 2005). Ancient Peruvians domesticated llamas and guinea pigs by $5500 \mathrm{BCE}$, settled into village life about $4300 \mathrm{BCE}$, and developed ceramic-making technology about 1800 BCE (Dobyns and Doughty 1976). Peru hosted important ancient civilizations including the Moche (c.100 to $700 \mathrm{CE}$ ) and Chimú (c 900 to $1470 \mathrm{CE}$ ) on the north coast, the Nazca (c.100 BCE to $800 \mathrm{CE}$ ) in the southern coastal region, and the Wari (c.500 to $1000 \mathrm{CE}$ ) in the Andes, but the most famous was the relatively short-lived Inca Empire (1438-1532). Centered in Cuzco in southeastern Peru, the Inca realm at its peak stretched 5500 miles from today's southern Colombia to northern Chile and included parts of Ecuador, Bolivia, and Argentina. The Incas incorporated local Indian groups who had long been domesticating animals and plants including maize and potatoes. The Incas and their predecessors terraced mountainsides for agriculture, raised hundreds of different varieties of potatoes with a type of spud for each microclimate (Pollan 2002, pp. 192194), and built and rebuilt impressive structures out of stone. The Incas themselves were master stonemasons who constructed numerous high altitude cities and agricultural terraces along with mountainside stone stairways and trails to connect them (Heaney 2011; Mann 2005). 
When Francisco Pizarro and 168 Spanish Conquistadors arrived in 1532, the Incas already had been weakened by a war of succession between Atahualpa and Huáscar, the sons of emperor Huayna Capac who along with another son, his chosen heir, had died sometime between 1524 and 1528 (accounts vary) in a smallpox epidemic. Infectious diseases introduced by the Europeans tore through the Americans and often reached indigenous populations before their first direct contact with the invaders (Mann 2005). Atahualpa triumphed over his half-brother, but was later seized by the Spaniards and murdered in 1533. Vestiges of the Inca Empire lasted in remote areas until 1572 when the last emperor, Túpac Amaru, was captured and executed. Meanwhile, repeated waves of epidemics decimated the indigenous peoples. Historian Noble David Cook (1998) estimates that largely because of infectious diseases, the Inca population declined from 9 million in 1520 to 600,000 in 1620 .

Pre-Columbian Peruvian civilizations produced a great number of objects made of bone, feathers, textiles, and wood that, because of the very arid coastal climate and dry mountain air, have survived along with typically more imperishable ceramics and precious metals. Most Peruvian antiquities extant today were once grave goods buried many centuries ago and then later excavated. Figure 1 illustrates four examples with outstanding aesthetic qualities, three of which are currently housed in American museum collections (one has been repatriated to Peru). They include a Moche pottery portrait vessel (c.100-500 CE), a Wari culture sculpture made from wood with shell, stone, and silver inlay (c.600-1000 CE), a Sican culture gold cup (c.850-1050 CE), and an Inca pottery small aryballos used to carry oils or perfumes (c.1500 CE). As will be shown later, objects on today's collectors' market are usually much less visually stunning although still quite attractive in terms of design and cultural associations. In addition to material goods, the Incas mummified their emperors and their customs included parading about the remains of dead rulers. The Spanish destroyed many of these mummies (mallquis in the Quechan language), but other human remains went untouched until several centuries later when foreigners acquired a number of them. These bones became entangled with the collecting of other cultural artifacts (Heaney 2011).

Figure 1. Museum quality Peruvian antiquities. Clockwise starting upperleft: Moche pottery portrait vessel c. 100-500 CE (Worcester Art Museum); Wari culture sculpture made from wood with shell, stone, and silver inlay c. 600-1000 CE (Kimbell Art Museum); Sican culture gold cup c. 850-1050 CE (Worcester Art Museum); Inca pottery small aryballos 
used to carry oils or perfumes c. 1500 CE (Yale Peabody Museum repatriated to Cuzco Museum, Peru).
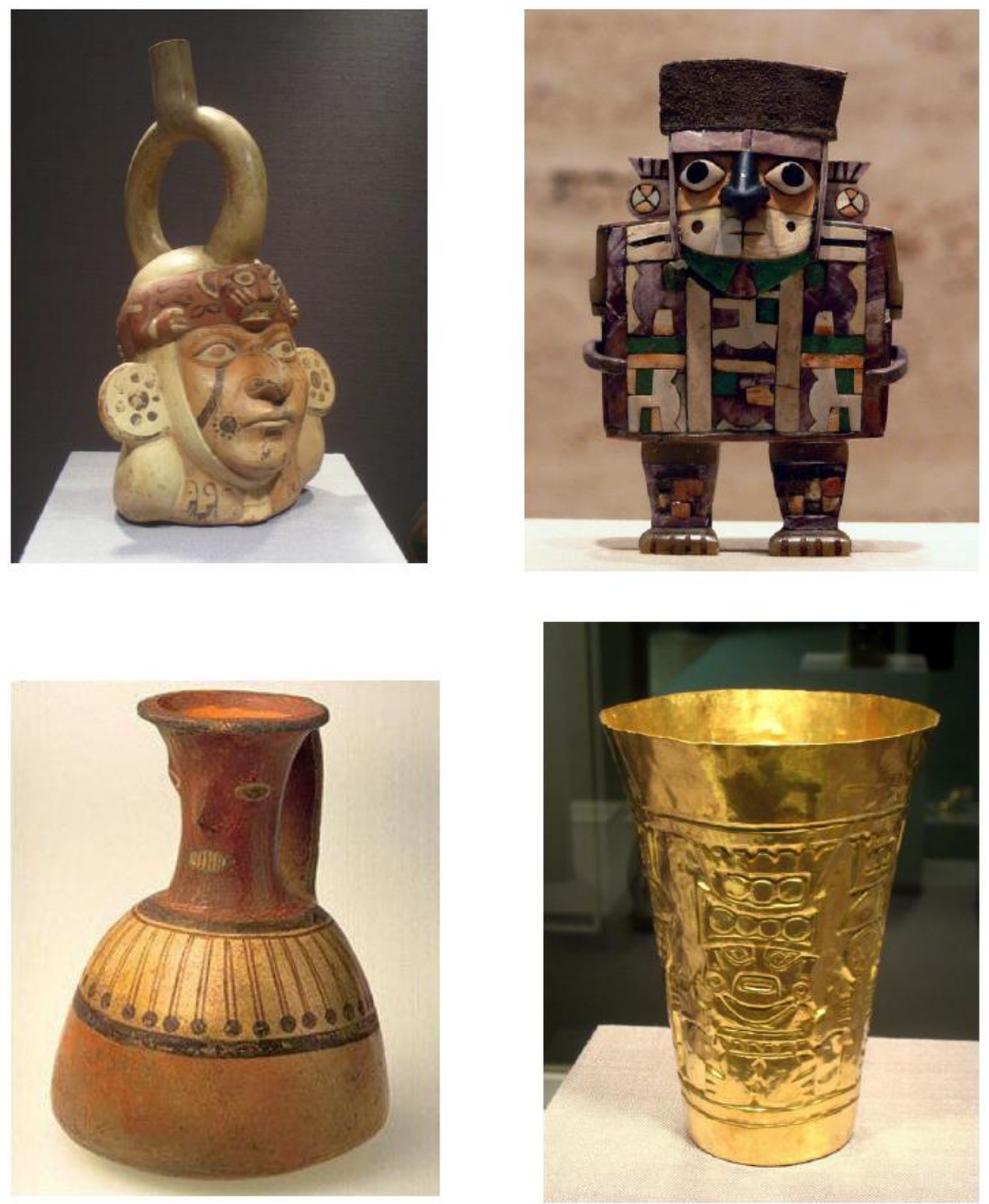

\section{The Collecting of Peruvian Artifacts}

The Conquistadors ransacked the Inca Empire for gold and silver objects and succeeding generations of looters stripped many graves and building sites of any remaining precious metals as well as accessible pottery. During the revolution against Spain, protection of ancient ruins and artifacts became a priority and, according to the Decreto Supremo (Executive Order) of 1822, ancient monuments and their contents belonged to the Peruvian nation and the extraction of precious metals and ceramics without authorization was prohibited (Heaney 2011). However, the buying, selling, and exporting of artifacts was not explicitly banned and collectors acquired more and more pieces one way or another. Although 
zeal for collecting things Peruvian paled in comparison to the international craze for obtaining Egyptian, Greek, Roman, and Middle-Eastern antiquities, interest did begin to grow among Europeans in the later nineteenth century, as well as among enthusiastic local collectors in Cuzco, Lima, and Santiago, Chile (Gänger 2014). Figure 2 depicts the impressive collection of Emilio Montes published in 1873 in the newspaper El Correro del Perú, volume IV (Gänger 2014, p. 53). A decreto issued in August 1911 finally got around to banning the export of artifacts (Heaney 2011).

Figure 2. Photo of the collection of Emilio Montes published in 1873 in the newspaper El Correro del Perú, volume IV (from Gänger 2014, p. 53)

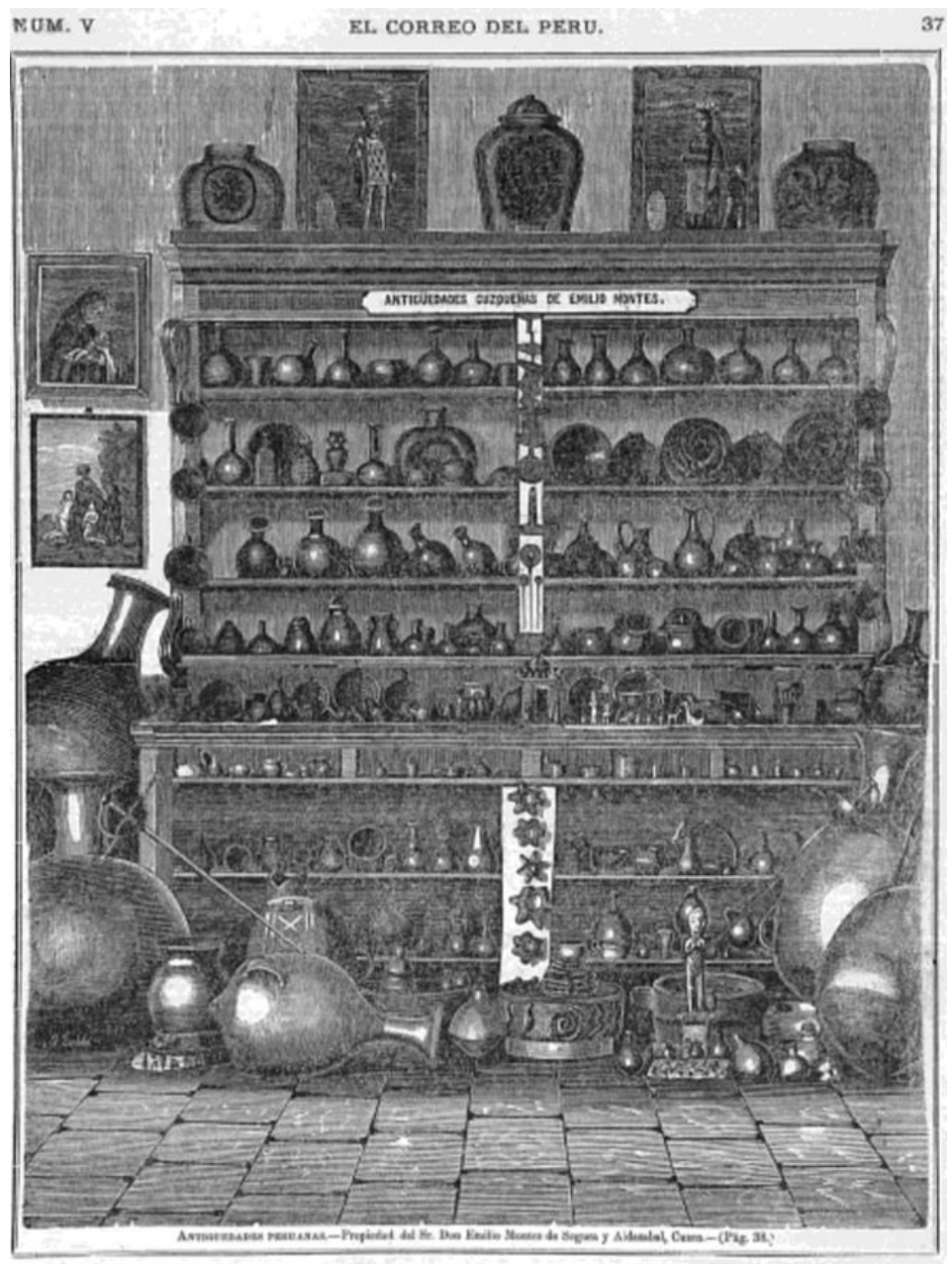


The timing of the new law had much to do with the visit of the American explorer and Yale Professor, Hiram Bingham III (1875-1956), who the previous month had "discovered" Machu Picchu during an expedition in search of Inca cities (Heaney 2011). Local Indians knew about this spectacular site and a few lived among its ruins, but for the wider world Bingham's written accounts and photographs, published in books and National Geographic articles, were a revelation. Sponsored by Yale University and the National Geographic Society, Bingham made subsequent trips in 1912, 1914, and 1915. In 1912, he brought back thousands of objects from Machu Picchu including ceramics, tools, jewelry, and human skeletons.

Bingham's adventures, writings, and lectures made him famous and undoubtedly fired the imaginations of scholars, museum curators, and private collectors for Peruvian antiquities. Bingham himself was not immune to these acquisitive impulses. Heaney (2011) mentions how Bingham casually helped himself to a small pottery object found in a burial niche during his first visit to Machu Picchu. In 1914, drawing from ample family funds - the tall and handsome Bingham had married Alfreda Mitchell, an heiress to the Tiffany fortune - he spent today's equivalent of $\$ 160,000$ to acquire an exquisite collection of 366 pre-Conquest artifacts the owner had pulled from graves and ruins or purchased from Indians or dealers. Customs officials had to be bribed in order to smuggle the loot out of Peru (Heaney 2011). Other local antiquarians offered Bingham their collections and in 1915 he purchased an assemblage of very nice ceramics from Nazca. The seller's brother worked in customs and the shipment left the country without a hitch (Heaney 2011). Bingham donated both collections to the Yale Peabody Museum. He later served as an aviator in World War I, became a U.S. Senator, and years after his death inspired the creation of the Indiana Jones character in the 1981 film Raiders of the Lost Ark.

Looting and trafficking of Peruvian antiquities undoubtedly continued through the twentieth century to supply demand from Western collectors and museums and probably accelerated in the 1980s when military repression led to the guerilla revolt of the Shining Path Maoists. In his article and subsequent book, both titled Stealing History, journalist Robert Atwood $(2002,2004)$ tells how the archaeological excavation of the royal tombs in Sipán between 1987 to 1990, and followed by the spectacular traveling exhibit "Royal Tombs of Sipán" from 1993 to 1995 (Gero 1997), kindled a twenty-year gold rush of looting in the immediate area and throughout Peru and other Andean countries. The professional looters are known locally as huaqueros, which derives from the indigenous 
Quechua language word huaca referring to a sacred place or, today, means an archaeological site like a burial pyramid (Yates 2012). They have been joined by local villagers who glean ravaged sites for leftovers after the huaqueros have departed. Meanwhile, landowners have used bulldozers to plow into tombs on their land. Atwood (2004, p. 73) believes the depredations of the 1980s and 1990s the most severe since the Spanish Conquest. Aerial photographs of some regions in Peru depict tens of thousands of holes left by diggers. These assaults on Peruvian heritage have continued. Yates (2014) describes looting incidents in 2009 and 2011 at the Dos Cabeza Moche cultural site on Peru's north coast. In 2013 developers razed a 4000 year-old pyramid at El Paraíso in the Lima metropolitan area (Dominguez 2013) and in 2015 a self-proclaimed property owner leveled the archaeological site of Farfán in Cajamarca in the northern Andes (Greenwood 2015).

Some looted material has been repatriated to Peru. Atwood (2004) describes at length how a number of valuable artifacts, including outstanding objects made from gold and taken from the Royal Tombs of Sipán and smuggled into the U.S., have been returned to Peru through the efforts of American police, customs agents, and the FBI. In 2012, Yale University agreed to repatriate the objects Hiram Bingham had taken back to America (Donadio 2014; Lubow 2007). The Peruvian government had given permission to take them to the U.S. for study, but with the stipulation that they were to be returned to Peru when requested (Heaney 2011). Some were returned after World War I, but most remained in the Yale Peabody Museum until the Peruvian government sued Yale for breach of contract contending that the original agreement giving Bingham permission to remove the artifacts was for short-term study at Yale, not for permanent keeping. In January 2016, Argentina returned 4,500 artifacts to Peru and Ecuador most of which probably having been looted from northern Peru (Economist 2016).

\section{The Contemporary Market for Peruvian Antiquities}

\section{Antiquity Market Concepts}

Of importance to understanding the operation of the collectors market for Peruvian and other antiquities are the key concepts of relocation, delocation, provenience, and provenance. Relocation and delocation are the processes by which the market re-contextualizes artifacts physically and in terms of their identity (Fay 2011; Geismar 2001). Artifacts looted from sites in Peru have been relocated to urban auction houses and dealer's showrooms, as well as directly to private parties, often far away in North America and Europe (the left-hand side of Figure 3). Typical 
intermediaries have included local or expatriate dealers living in Peru, typically Lima, who have enlisted malleable government officials and customs agents to grease the wheels to ensure that the items could leave the country (Atwood 2004). As they make their journey to market, pieces have been cleaned and may have undergone some repairs and "restorations." Careless excavation and subsequent handling of fragile materials has frequently resulted in damage to artifacts.

\section{Figure 3. A Model of the Antiquities Trade}

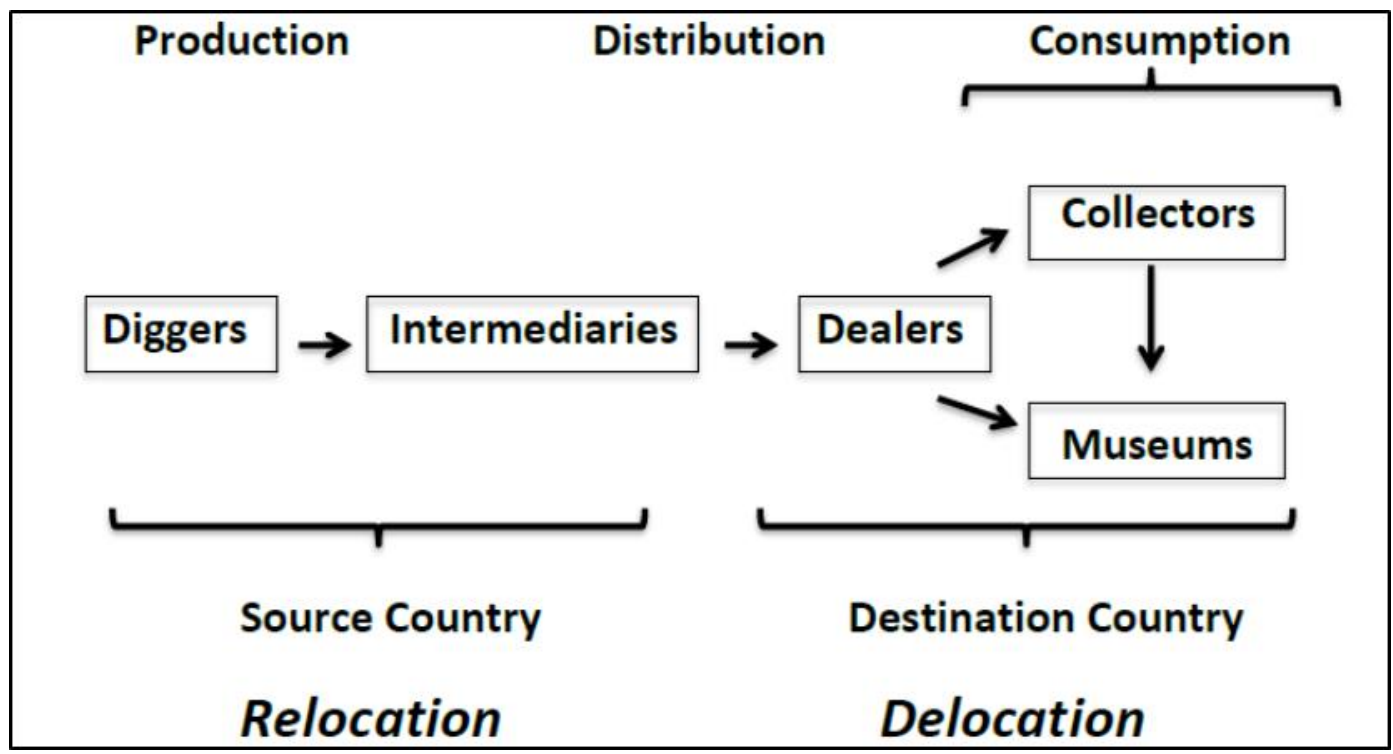

Source: Adapted from Brodie (2011).

After being transported and transformed, Peruvian antiquities then have been delocated (the right-hand side of Figure 3 ) through the acquisition of a new identity as they passed through the market. Authenticity is a key feature of this identity since the allure and monetary value of antiquities is based in large part upon their providing a tangible link to the past. Authentic identity has been built through provenience and provenance. Provenience means that the context in which an artifact was found can be documented. For example, antiquities retrieved by government-sanctioned digs operating under professional archaeological supervision have strong provenience. However, most items have come to market by more surreptitious means and, therefore, lack verifiable contextual information. For these artifacts authenticity has been built through provenance, a history of their ownership and association, and also of the guarantee of authenticity offered by the seller. Being sold by 
prestigious auction houses, such as Christies and Sotheby's, provides a good start to the delocation process, but smaller dealers have participated as well (Atwood 2004; Fay 2011; Geismar 2001). Like other antiquities, some Peruvian items have been sold over and over again by collectors (or their heirs) to private dealers and through public auctions. Undoubtedly, information about provenience and provenance has been lost in the resale process at times because of seller reticence and buyer incuriosity. Thus, delocation is a process that sometimes must begin anew.

\section{The Internet and Antiquity Markets}

The Internet has facilitated a more liquid global market for small, portable antiquities (Brodie 2015; Fay 2011). Sites include eBay (launched in 1995), Internet malls hosting individual dealers (e.g., Trocadero), and online auctions from established international companies (e.g., Christies and Sotheby's) and many other smaller firms that can now more easily reach a community of collectors worldwide. Online antiquities marketing not only reaches buyers from different socioeconomic levels, but also favors dealers who can sell lower value items without having to have a costly physical retail presence (Brodie 2015). Not all of this market activity involves recently looted artifacts. Some objects left their source countries many decades or even centuries ago before national laws and international conventions governing exports had been enacted. Purchases of more recently excavated antiquities may also be legitimate through sales, such as those of salvaged shipwreck ceramics with many multiple items (Pope 2007), approved by source or transit country governments.

Delocation occurs, whether online or in retail stores and at antique shows, when dealers make claims about object age, type, purpose, and source country, but may be reticent when it comes to revealing how they came upon their wares. Listings on eBay provide written and visual evidence of delocation in action. In her study of 494 antiquities of all types whose listings on eBay ended on October 5, 2008, Fay (2011) found no evidence of provenience. However, $65 \%$ of the listings did discuss provenance in terms of source country and recent collecting history (e.g. via a statement such as "Ex British private collection"). In Fay's (2011) sample, $57 \%$ of objects with no provenance resulted in a sale, whereas $76 \%$ of those with documentation sold. Sixty-one percent of the sellers in Fay's (2011) sample guaranteed authenticity, although details about what this assurance would mean in practice were usually not included. 


\section{Online Sales of Peruvian Antiquities}

Fay's (2011) methods were adopted to explore the scale, scope, and financial value of the eBay marketplace for Peruvian antiquities. Object types, materials, and offering prices were recorded from a set of listings, along with seller claims about provenience and provenance. The accuracy of dealer assertions regarding authenticity cannot be determined, but what they emphasize in their descriptions does give some insight into how antiquity market actors think about these artifacts.

On March 31, 2016 I examined listings on the American version of eBay under the search term "pre-Columbian Peruvian antiques." These probably do not represent the entire universe of Peruvian antiquities available on eBay, but provide enough data for a snapshot of this segment of the market. The search term turned up 30 listings. Preliminary inspection showed that one listing was for reference books, two were for replicas, and one more did not appear Peruvian. These were eliminated from further consideration. For the remaining 26 listings, two screenshots with the most pertinent information were saved along with one image download. The results are presented in Table 1 and selected illustrations are shown in Figures 4, 5 and 6.

\section{Table 1. Exploratory Study of eBay Listing of "Pre-Columbian}

\section{Peruvian Antiquities"}

\begin{tabular}{|c|c|c|c|c|c|}
\hline $\begin{array}{l}\text { Item \# / } \\
\text { Exp. } \\
\text { Date }\end{array}$ & Item Listing & $\begin{array}{l}\text { Current } \\
\text { Bid as of } \\
31-3-2016\end{array}$ & Size & $\begin{array}{l}\text { Pro- } \\
\text { venience }\end{array}$ & Provenance \\
\hline $\begin{array}{l}1 . / \\
1-4-16\end{array}$ & $\begin{array}{l}\text { Antique Ancient } \\
\text { Peruvian Chimu } \\
\text { Pre-Columbian } \\
\text { Pottery Figural } \\
\text { Whistling Vessel }\end{array}$ & $\begin{array}{l}\$ 110.00 \\
\text { (SB) } \\
\text { (relisted 1- } \\
4-16)\end{array}$ & $\begin{array}{l}1.5 \times 1 \times \\
2 \text { in. }\end{array}$ & No & $\begin{array}{l}\text { Estate of David May II } \\
\text { of May Department } \\
\text { Stores (Leadville and } \\
\text { Denver, CO, 1877- } \\
2005 \text { ) }\end{array}$ \\
\hline $\begin{array}{l}2 . / \\
1-4-16\end{array}$ & $\begin{array}{l}\text { Small Archaic } \\
\text { Antique Peruvian } \\
\text { Pre-Columbian } \\
\text { Chimu Blackware } \\
\text { Pottery Spout Jar }\end{array}$ & $\begin{array}{l}\$ 180.00 \\
\text { (SB) } \\
\text { (Sold?) }\end{array}$ & $\begin{array}{l}2.75 \mathrm{x} \\
1.75 \\
\times 2.5 \mathrm{in} .\end{array}$ & No & $\begin{array}{l}\text { Estate of David May II } \\
\text { of May Department } \\
\text { Stores (Leadville and } \\
\text { Denver, CO, 1877- } \\
\text { 2005) }\end{array}$ \\
\hline $\begin{array}{l}3 . / \\
1-4-16\end{array}$ & $\begin{array}{l}\text { Antique Pre- } \\
\text { Columbian Peruvian } \\
\text { Pottery Pitcher }\end{array}$ & $\begin{array}{l}\$ 10.00 \\
\text { (RNM) } \\
\text { (Sold for } \\
\$ 75.00)\end{array}$ & $\begin{array}{l}7.25 x \\
7.25 \mathrm{in.}\end{array}$ & No & $\begin{array}{l}\text { Purchased by dealer's } \\
\text { cousin in early } 1970 \text { s in } \\
\text { Cuzco }\end{array}$ \\
\hline $\begin{array}{l}4 . / \\
1-4-16\end{array}$ & $\begin{array}{l}\text { Antique Pre- } \\
\text { Columbian Peruvian } \\
\text { Pottery Blackware } \\
\text { Urn Vase }\end{array}$ & $\begin{array}{l}\$ 10.00 \\
\text { (RNM) } \\
\text { (relisted 2- } \\
4-16 \text { ) }\end{array}$ & $\begin{array}{l}5.75 \times 6 \\
\text { in. }\end{array}$ & No & $\begin{array}{l}\text { Purchased by dealer's } \\
\text { cousin in early } 1970 \text { s in } \\
\text { Cuzco }\end{array}$ \\
\hline $\begin{array}{l}5 . / \\
1-4-16\end{array}$ & $\begin{array}{l}\text { Antique Pre- } \\
\text { Columbian Peruvian } \\
\text { Pottery Face Vase }\end{array}$ & $\begin{array}{l}10.00 \\
\text { (RNM) } \\
\text { (relisted 2- }\end{array}$ & $6 \times 4.5 \mathrm{in}$. & No & $\begin{array}{l}\text { Purchased by dealer's } \\
\text { cousin in early } 1970 \text { s in } \\
\text { Cuzco }\end{array}$ \\
\hline
\end{tabular}




\begin{tabular}{|c|c|c|c|c|c|}
\hline & & $4-16)$ & & & \\
\hline $\begin{array}{l}6 . / \\
2-4-16\end{array}$ & $\begin{array}{l}\text { Pre Columbian } \\
\text { Textile Antique } \\
\text { Native Peruvian } \\
\text { Figural Weaving } \\
\text { Inca Culture }\end{array}$ & $\begin{array}{l}\$ 139.99 \\
(\mathrm{BIN})\end{array}$ & $17 \times 6$ in. & No & None \\
\hline $\begin{array}{l}7 . / \\
3-4-16\end{array}$ & $\begin{array}{l}\text { Pre-Columbian - } \\
\text { Peruvian Ceramica } \\
\text { Moche or Chimu - } \\
\text { Erotic }\end{array}$ & $\begin{array}{l}\$ 290.00 \\
(\mathrm{SB})\end{array}$ & $\begin{array}{l}7.87 \mathrm{x} \\
8.27 \mathrm{in.}\end{array}$ & No & None \\
\hline $\begin{array}{l}8 . / \\
5-4-16\end{array}$ & $\begin{array}{l}\text { Antique Vintage } \\
\text { Pre-Columbian } \\
\text { Peruvian Chancay } \\
\text { Folk Art Doll Mother } \\
\text { with Baby }\end{array}$ & $\begin{array}{l}\$ 32.95 \\
(\mathrm{BIN})\end{array}$ & $11 \times 3$ in. & No & None \\
\hline $\begin{array}{l}9 . / \\
5-4-16\end{array}$ & $\begin{array}{l}\text { Pre Columbian } \\
\text { Peruvian Moche } \\
\text { Pottery Figural } \\
\text { Vessel Vase }\end{array}$ & $\begin{array}{l}\$ 300.00 \\
\text { (1Bid) }\end{array}$ & $\begin{array}{l}9 \times 4.5 \times \\
6 \text { in. }\end{array}$ & No & None \\
\hline $\begin{array}{l}10 . / \\
6-4-16\end{array}$ & $\begin{array}{l}\text { Antique Vintage } \\
\text { Pre-Columbian } \\
\text { Peruvian Chancay } \\
\text { Doll Mother w/Baby }\end{array}$ & $\begin{array}{l}\$ 29.99 \\
(\mathrm{BIN})\end{array}$ & & No & None \\
\hline $\begin{array}{l}11 . / \\
8-4-16\end{array}$ & $\begin{array}{l}\text { Antique Pre- } \\
\text { Columbian Peruvian } \\
\text { Chimu Primitive } \\
\text { Pottery Monkey } \\
\text { Sculpture Whistle }\end{array}$ & $\begin{array}{l}\$ 165.32 \\
(\mathrm{BIN}) \\
\text { note } \\
\text { discount }\end{array}$ & $\begin{array}{l}6.75 \mathrm{x} \\
4.25 \mathrm{x} \\
6.75 \mathrm{in.}\end{array}$ & No & $\begin{array}{l}\text { Purchased from local } \\
\text { estate as Pre- } \\
\text { Columbian and has } \\
\text { been in the family for } \\
\text { decades but that is } \\
\text { really all the information } \\
\text { I have. }\end{array}$ \\
\hline $\begin{array}{l}12 . / \\
8-4-16\end{array}$ & $\begin{array}{l}\text { Antique Pre- } \\
\text { Columbian Peruvian } \\
\text { Chimu Primitive } \\
\text { Pottery Monkey } \\
\text { Sculpture Peru }\end{array}$ & $\begin{array}{l}\$ 1067.50 \\
\text { (BIN) } \\
\text { note } \\
\text { discount }\end{array}$ & $\begin{array}{l}3.5 \times \\
4.75 \times 5 \\
\text { in. }\end{array}$ & No & $\begin{array}{l}\text { Purchased from local } \\
\text { estate as Pre- } \\
\text { Columbian and has } \\
\text { been in the family for } \\
\text { decades but that is } \\
\text { really all the information } \\
\text { I have. }\end{array}$ \\
\hline $\begin{array}{l}13 . / \\
8-4-16\end{array}$ & $\begin{array}{l}\text { Antique Pre- } \\
\text { Columbian Peruvian } \\
\text { Chancay Pottery } \\
\text { Vessel } \\
\text { Hippopotamus } \\
\text { Redware Horse }\end{array}$ & $\begin{array}{l}\$ 899.75 \\
(\mathrm{BIN}) \\
\text { note } \\
\text { discount }\end{array}$ & $\begin{array}{l}5 \times 6.25 \times \\
3.75 \text { in. }\end{array}$ & No & $\begin{array}{l}\text { Purchased from local } \\
\text { estate as Pre- } \\
\text { Columbian and has } \\
\text { been in the family for } \\
\text { decades but that is } \\
\text { really all the information } \\
\text { I have. }\end{array}$ \\
\hline $\begin{array}{l}14 . / \\
8-4-16\end{array}$ & $\begin{array}{l}\text { Antique Pre- } \\
\text { Columbian Peruvian } \\
\text { Chancay Pottery } \\
\text { Vase Mouse } \\
\text { Primitive Horse Jar }\end{array}$ & $\begin{array}{l}\$ 358.07 \\
\text { (BIN) } \\
\text { note } \\
\text { discount }\end{array}$ & $\begin{array}{l}4.5 \times .4 .5 \\
\times 3.25 \text { in. }\end{array}$ & No & $\begin{array}{l}\text { Pre-Columbian and has } \\
\text { been in the family for } \\
\text { decades but that is } \\
\text { really all the information } \\
\text { I have. }\end{array}$ \\
\hline $\begin{array}{l}15 . / \\
8-4-16\end{array}$ & $\begin{array}{l}\text { Antique Pre- } \\
\text { Columbian Peruvian } \\
\text { Chimu Primitive } \\
\text { Pottery Cat } \\
\text { Sculpture Peru }\end{array}$ & $\begin{array}{l}\$ 1311.50 \\
(\mathrm{BIN}) \\
\text { note } \\
\text { discount }\end{array}$ & $\begin{array}{l}9 \times 4 \times \\
6.25 \text { in. }\end{array}$ & No & $\begin{array}{l}\text { Pre-Columbian and has } \\
\text { been in the family for } \\
\text { decades but that is } \\
\text { really all the information } \\
\text { I have. }\end{array}$ \\
\hline $16 . /$ & Antique Pre- & $\$ 1128.50$ & $3.25 x$ & No & Pre-Columbian and has \\
\hline
\end{tabular}




\begin{tabular}{|c|c|c|c|c|c|}
\hline $8-4-16$ & $\begin{array}{l}\text { Columbian Peruvian } \\
\text { Chimu Primitive } \\
\text { Pottery Monkey } \\
\text { Man Small Pot Jar }\end{array}$ & $\begin{array}{l}\text { (BIN) } \\
\text { note } \\
\text { discount }\end{array}$ & $5.75 \mathrm{in.}$ & & $\begin{array}{l}\text { been in the family for } \\
\text { decades but that is } \\
\text { really all the information } \\
\text { I have. }\end{array}$ \\
\hline $\begin{array}{l}17 . / \\
8-4-16\end{array}$ & $\begin{array}{l}\text { Antique Pre- } \\
\text { Columbian Peruvian } \\
\text { Chimu Primitive } \\
\text { Pottery Decanter } \\
\text { Indian Chief }\end{array}$ & $\begin{array}{l}\$ 358.07 \\
(\mathrm{BIN}) \\
\text { note } \\
\text { discount }\end{array}$ & $\begin{array}{l}7.75 \times \\
3.5 \times 6 \text { in. }\end{array}$ & No & $\begin{array}{l}\text { Pre-Columbian and has } \\
\text { been in the family for } \\
\text { decades but that is } \\
\text { really all the information } \\
\text { I have. }\end{array}$ \\
\hline $\begin{array}{l}18 . / \\
9-4-16\end{array}$ & $\begin{array}{l}\text { Antique Chancay } \\
\text { Primitive Peruvian } \\
\text { Inca Grave Dolls- } \\
\text { Pre-Columbian } \\
\text { Handmade burla }\end{array}$ & $\begin{array}{l}\$ 48.75 \\
(\mathrm{BIN}) \\
\text { note } \\
\text { discount }\end{array}$ & 11 in & No & Living estate liquidation. \\
\hline $\begin{array}{l}19 . / \\
11-4-16\end{array}$ & $\begin{array}{l}\text { Pre columbian } \\
\text { Textile Bag? } \\
\text { Antique Native } \\
\text { Peruvian Weaving } \\
\text { Inca Culture }\end{array}$ & $\begin{array}{l}\$ 159.99 \\
\text { (BIN) }\end{array}$ & & No & None \\
\hline $\begin{array}{l}20 . / \\
17-4-16\end{array}$ & $\begin{array}{l}\text { Pre Columbian } \\
\text { textiles Peruvian } \\
\text { pictorial fragments }\end{array}$ & $\begin{array}{l}\$ 590.00 \\
(B I N)\end{array}$ & $\begin{array}{l}\text { Top 3: } \\
26.5 \times 24 \\
\text { in. Lower: } \\
16 \times 7 \text { in. }\end{array}$ & No & None \\
\hline $\begin{array}{l}21 . / \\
21-4-16\end{array}$ & $\begin{array}{l}\text { A Rare Peruvian } \\
\text { pre-Columbian } \\
\text { Chancay Chimu } \\
\text { ceramic pottery } \\
\text { vessel w. dog }\end{array}$ & $\begin{array}{l}\$ 595.00 \\
\text { (BIN) }\end{array}$ & $\begin{array}{l}7 \times 7 \times 4 \\
\text { in. }\end{array}$ & No & $\begin{array}{l}\text { This item was acquired } \\
\text { from the estate of the } \\
\text { late Mrs. Lynn Wolfson } \\
\text { of Miami }\end{array}$ \\
\hline $\begin{array}{l}22 . / \\
21-4-16\end{array}$ & $\begin{array}{l}\text { Ancient Pre } \\
\text { Columbian Chimu } \\
\text { Peruvian Whistling } \\
\text { Vessel - } 1470 \mathrm{AD}\end{array}$ & $\begin{array}{l}\$ 1565.00 \\
(\mathrm{BIN})\end{array}$ & $6.5 \times 8$ in. & No & $\begin{array}{l}\text { Ex. Collection of Arthur } \\
\text { M. Sackler, 1913-1987. }\end{array}$ \\
\hline $\begin{array}{l}23 . / \\
21-4-16\end{array}$ & $\begin{array}{l}\text { Pre-Columbian } \\
\text { Large Collection of } \\
\text { Peruvian Copper } \\
\text { (Lot of 12) }\end{array}$ & $\begin{array}{l}\$ 2700.00 \\
(\mathrm{BIN})\end{array}$ & varies & No & None \\
\hline $\begin{array}{l}24 . / \\
23-4-16\end{array}$ & $\begin{array}{l}\text { Pre-Columbian } \\
\text { Ancient Artifact } \\
\text { Peruvian South } \\
\text { America Statue } \\
\text { Figurine Sculpture }\end{array}$ & $\begin{array}{l}\$ 1799.10 \\
(\mathrm{BIN}) \\
\text { note } \\
\text { discount }\end{array}$ & $8 \times 3$ in. & No & $\begin{array}{l}\text { Father purchased at } \\
\text { auction when seller was } \\
5 .\end{array}$ \\
\hline $\begin{array}{l}25 . / \\
24-4-16\end{array}$ & $\begin{array}{l}\text { Antique Peruvian } \\
\text { Pre Columbian } \\
\text { Artifact Figural } \\
\text { Pottery Scupture }\end{array}$ & $\begin{array}{l}\$ 99.99 \\
\text { (BIN) }\end{array}$ & $\begin{array}{l}5.75 \times \\
4.5 \times 2 \mathrm{in} .\end{array}$ & No & $\begin{array}{l}\text { Purchased from former } \\
\text { Pre Columbian } \\
\text { Professor [sic] here at a } \\
\text { local university. }\end{array}$ \\
\hline $\begin{array}{l}26 . / \\
25-4-16\end{array}$ & $\begin{array}{l}\text { Antique } 1500 \text { 's Pre } \\
\text { Columbian Peruvian } \\
\text { handmade textile } \\
\text { rug Peru } \\
\text { needlepoint rare }\end{array}$ & $\begin{array}{l}\$ 1239 \\
\text { (BIN) }\end{array}$ & $\begin{array}{l}13 \times 27 \\
\text { in. }\end{array}$ & No & None \\
\hline
\end{tabular}

Notes: 1) Expiration and other dates are written day-month-year. 2) Bid Acronyms are $\mathrm{SB}=$ starting bid, $\mathrm{RNM}=$ reserve not met, and $\mathrm{BIN}=$ buy it now. 
Figure 4. Examples of Peruvian antiquities found on eBay on March 31, 2016. Clockwise starting upper left: Items 3, 4, 5 (all in first photo), 6 , 7 , and 8 (probably not an antiquity).
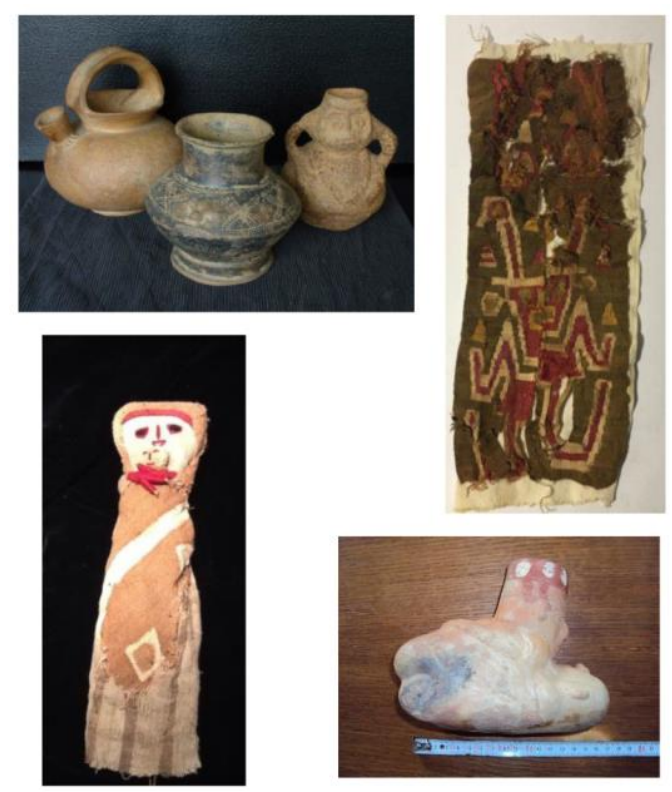

Figure 5. Examples of Peruvian antiquities found on eBay on March 31, 2016. Clockwise starting upper left: Items 9, 12, 13, 14.
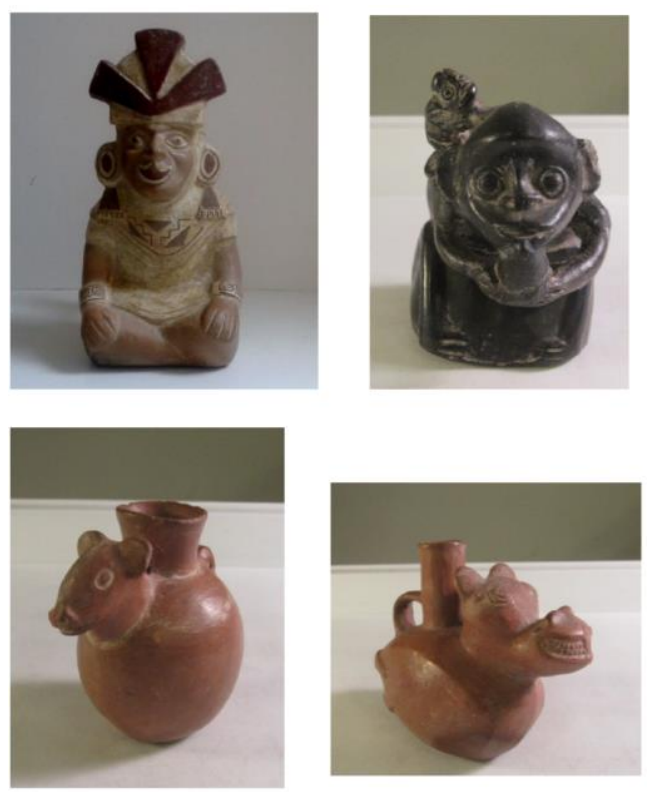
Figure 6. Examples of Peruvian antiquities found on eBay on March 31, 2016. Clockwise starting upper left: Items 20, 21, 23, 24.
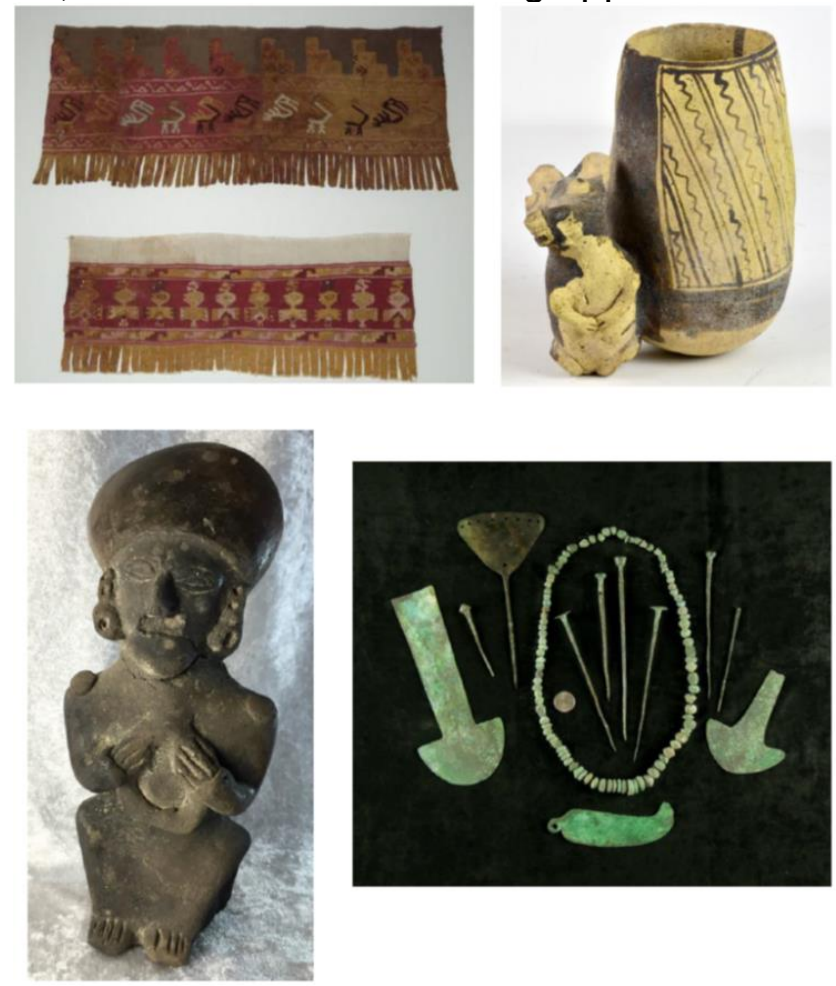

The items included pottery, textiles, and metals. Seven were at auction and 19 were offered at "Buy It Now" prices. The "Buy It Now" items ranged from $\$ 29.99$ for a Chancay doll to $\$ 2700$ for a collection of copper objects. Dealers offered nine of the items at a discount from previous listings. Items 8 and 10, the Chancay dolls, are probably not antiquities. They appear newish and are priced much lower than other textile objects. Some of the others also may be reproductions that were once passed off as antiquities, but this is difficult to determine online and even the most knowledgeable collector would be taking a chance. None of the 26 listings mentioned provenience (site location, excavation date), while 17/26 (65\%, the same percentage Fay reported) had some, usually vague description of provenance (history of ownership). For example, dealer "moto 1800" from Yonkers, New York said this about three pieces listed (items 3, 4, and 5 in Figure 4 and Table 1): "All three were purchased by my late cousin in the early 70's in Cuzco, Peru while he was traveling across the SA continent. He was positive about their authenticity". Dealer "ambassadors" from Portland, Oregon said this about items 11-17, "I 
purchased this from a local estate as Pre-Columbian and they have been in the family for decades but this is really all the information I have."

I revisited "pre-Columbian Peruvian antiques" on eBay again on August 2, 2017. Of the 41 listings this time, three were reproductions and two more, judging from their offering prices and vague descriptions, appeared to be so. Three "burial dolls" offered by "kassan99" purportedly consisted of ancient textiles and modern components. In the following representation, the seller made vague references to provenience and provenance:

Peruvian Dolls made with ancient textiles of the Chancay Culture.

This doll was purchased in the 1960's by a New York collector. Depicting a woman, with hands and feet.

Made by Peruvian women using ancient textiles from the Chancay Culture which existed 1100-1400 years ago. The textiles are preColumbian. The women would gather ancient pieces of fabric from the area and make these dolls for the tourist trade so that they could earn a living. These ancient textiles were preserved in the dry climate.

In a very real way, these dolls blend the old and new and you can own a piece of that history.

10 by 4 inches

25.4 by $10.16 \mathrm{~cm}$

The statement, "you can own a piece of that history," appeals to a powerful collecting motive. Another item, a silver-mounted textile box, incorporated original Inca period textiles in its construction. Asked prices for these nine questionable items ranged from $\$ 34.99$ to $\$ 188.00$. The 32 possibly authentic objects listed from $\$ 9.99$ (an auction starting offer) for some tiny Moche culture pendant fragments to $\$ 2700.00$ for the same, still for sale collection of copper objects mentioned above. The seller of six small ceramic objects, "firefly1052," claimed they were all purchased in Cuzco and vicinity in 1973. Only a couple of other listings mentioned any provenance whatsoever. Thus, not only are these objects being sold without much inkling as to their archaeological findspot and authenticity, but also dealers may be transferring looted merchandise illegally taken from Peru. Their aesthetic and historical attractions remain powerful, however, and many collectors are willing to ignore these inconvenient assessments. 


\section{Collecting Cultural Goods}

The formation of collectors markets and the development of marketing systems to serve them are macro processes with inevitable societal implications. This is clearly true of various antiquities markets that have provided satisfactions to participants, but ultimately have been responsible for some significant losses to source country cultural history and patrimony (Davis 2006; Miller 1992). Undoubtedly, the marketing and collecting of Peruvian antiquities, especially during and since the 1980s, has had profound consequences for the preservation of the nation's cultural heritage. According to critical observers, cultural knowledge has been degraded and sometimes even destroyed through looting activities (Atwood 2004; Yates 2015).

Private collectors, museum curators, dealers, auctioneers, their attorneys, and sympathetic academics have defended the antiquities market. As participants, these parties find buying and selling art and artifacts to be intellectually stimulating, exciting to negotiate, and, for the middlemen, financially rewarding. On the other side have been archaeologists, conservators, and representatives of source countries who decry the losses of cultural knowledge caused by looting to satisfy market demand. When it comes to antiquities, academic debates and international legal actions are about the protection of cultural heritage, sometimes about money, and often entail issues of identity and cultural nationalism (Cuno 2008). This section examines these larger controversies within the context of Peruvian antiquities and, by analyzing different stakeholder viewpoints, raises questions about their marketing and collecting.

\section{International Collector and Commercial Interests}

Since the nineteenth century collector demand from both private individuals and public institutions has driven the market for Peruvian antiquities. Collectors have been attracted to these objects because of their aesthetic qualities, their great age and history, and what they say about past Andean cultures. Private and institutional collecting has stimulated a scholarly interest in Peruvian heritage, which has resulted in professional excavations at sites such as Machu Picchu, Sipán, and others (Atwood 2004; Heaney 2011). Many museums in the U.S. and Europe built their antiquities collections through a system of "partage" where governments sanctioned excavation in return for claims on certain objects and percentages of sales (Cuno 2008). From a utilitarian perspective, collecting antiquities provides great satisfactions to participants. 
Defenders of the global antiquities market have contended that developing countries like Peru often lack the resources to properly store and protect their large and growing stockpiles of artifacts. Private and institutional collectors in rich nations can provide better care and, by diversifying ownership globally, help ensure that these antiques are more likely to survive into the future. Certainly, the destruction of the Bamiyan Buddhas by the Afghan Taliban in 2001 and the looting and destruction of artifacts and architecture by Islamic State in Iraq and Syria in 2014-2017 lends ample credence to this argument. Further, by spreading pieces around the world in private and public collections, more people have an opportunity to see and appreciate them and thereby acquire greater cultural understanding. Proponents of this last argument, the so-called "cultural internationalist" perspective, have accused source countries for being "retentionists" and for using antiquities to advance nationalistic identity projects controlled by elites (Cuno 2008). Finally, some have argued that attempts to criminalize the trade in antiquities create black markets that are harder to control than would be the hypothetical managed markets they propose (Borodkin 1995; Gerstenblith 2007; Merryman 2005).

Atwood (2004, p. 154) notes several missing elements in this case for the antiquities market: "These advocates rarely accompanied their argument with calls for restraint by collectors, appeals to responsibility, or any call for sacrifice at all from collectors while at the same time upholding the market's right to extract a vital sacrifice from source countries, namely, their cultural heritage". The antiquities market seemingly ignores basic tenets of principled consumption. In contrast, the late John Merryman (1986), a pro-market Stanford law professor, opined that looters and smugglers do a service by uncovering hidden treasures and transporting them to safety in rich world collections. From time to time others from this side have accused archaeologists of being elitists who sometimes do damage themselves through shoddy science. At the Museo Machu Picchu in Cuzco in August 2016, I read descriptive material alleging that Hiram Bingham and his teams did not practice the state-of-the-art archaeological (stratigraphic) research techniques of the day.

\section{Scientific, Cultural, and National Interests}

Archaeologists, their associations and institutions, and representatives of source countries argue fervently that the value put on art and artifacts by private collectors and public museums has given a strong financial incentive to ransacking cultural sites. In the case of Peru, as well as many other countries, looters have ranged from poor local villagers to better-off local landowners to opportunistic foreign visitors. The critics believe that 
graves and other findspots are better left undisturbed until professional archaeologists, whose stratigraphic methods help determine dates and context and thus save much valuable information, can excavate them. To make matters worse, looted antiquities may lose, sometimes deliberately, their provenience and provenance as they journey from seller to buyer to another seller. Sometimes anomalies that are authentic, but contradict established understanding, may be regarded as forgeries and, therefore, do not contribute to the sum of knowledge (Gerstenblith 2007).

International conventions take the side of the scientific establishment and the source countries for antiquities. In November 1970, the United Nations Educational Scientific and Cultural Organization adopted the Convention on the Means of Prohibiting and Preventing the Illicit Import, Export and Transfer of Ownership of Cultural Property 1970 (UNESCO 2017). Among other provisions, this convention assigns ownership of antiquities recovered after 1970 to source nations. Still, cross-border enforcement is difficult because individual nations must ratify the convention through national legislation. Currently, 131 nations are parties with a number of them having their own lists of additions and reservations to the convention (UNESCO 2017). In addition, in June 1976 the Organization of American States (OAS) approved the Convention on the Protection of the Archaeological, Historical, and Artistic Heritage of the American Nations (Convention of San Salvador). Unfortunately for the scientific interests, only 13 out of 35 OAS member nations including Peru have signed this treaty, but not Brazil, Canada, Colombia, Mexico, the U.S., Uruguay, Venezuela, and many others (OAS 2017).

Numerous Latin American countries have their own laws governing the export and import of antiquities. As mentioned, Peru passed decretos in 1822 and 1911 protecting cultural property and limiting its export. What is striking is how little respect traffickers, dealers, and collectors give to Peruvian laws and to the national laws of other source countries. However, Peruvian laws remain ambiguous and their enforcement spotty, which can give dealers and collectors a convincing line of defense when prosecuted in foreign courts. Atwood (2004, p. 217) attributes these legal shortcomings to the indifference of political elites in Lima.

\section{Local and Indigenous Interests}

According to Heaney (2011), a Peruvian saying goes "Incas sí, Indios no." The phrase basically means that while foreign archaeologists romanticize the pre-Conquest past, they ignore the indigenous present. This feeling has led some Indians to acts of hostility directed at Peruvian archaeologists. When word got out in 1987 that looters had uncovered a major tomb in Sipán, local police contacted Dr. Walter Alva, then director 
of the Brüning National Archaeological Museum in nearby Lambayeque. Alva organized the formal excavation of the site, found more tombs with a great wealth of exquisite objects that later populated the 1993-1995 traveling exhibition. He was feted in Peru and abroad and became well known for his tireless campaigns to stop such looting (Atwood 2004). However, local Indians despised him. Immediately after the team of looters had discovered the first tomb and absconded with their booty, hundreds of people from Sipán and other nearby villagers descended on the site to scavenge the backfill in search of any small objects that might have been missed. Police had to fire shots in the air to scatter them and then erect barbed wire and stay on patrol to keep them off the site. Later, the villagers threw rocks and hurled insults at Alva and his team members working at the site.

This image of local people despoiling their own heritage for small short-term gains, while at the same time assaulting archaeologists who seek to protect cultural goods for posterity, is deeply troubling. Yes, they were and are very poor and usually neglected by the government in Lima. Earning a little extra money selling some scraps of metal, pottery, and textiles to tourists and dealers bring a smidgeon of economic relief. But a possibly more telling contributory factor to these local assertions of looting rights is how indigenous Peruvians see themselves and their history. Centuries of subaltern status under the Spanish perpetuated since independence by elites - Peru, like other Latin American countries, suffers from high levels of income and wealth inequality - have inculcated a form of indigenous cultural rejection among Indian people (Atwood 2004). To make matters worse, poor locals in Peru and other source countries sell the artifacts they find to tourists and dealers for prices a fraction of their eventual market value.

Not all locals show such disrespect for their patrimony. Atwood (2004) tells how Alva and his colleagues organized patrols in Ucupe and eight other villages in north coastal Peru to combat commercial looting. Called a grupo de protección arqueológica or la grupa, they borrow from a long Peruvian tradition of rondas campesinas where peasants have organized to fight bandits, rustlers, land squatters, and even the Maoist Shining Path guerrillas. When suspicious activity is noted, the police are summoned. As mentioned previously, however, local landowners and developers also engage in the destruction of archaeological sites (Atwood 2004; Dominguez 2013; Greenwood 2015), and they may be even harder to control than villagers given their greater financial resources and political influence that could be used to game the system. Archaeological sites and museums can attract tourists whose spending may facilitate local 
economic development (Brodie 2002). In 2002 a new Royal Tombs Museum of Sipán (Museo Tumbas Reales de Sipán) was opened in Lambayeque, Peru and in 2009 a smaller facility was opened at the excavation site several miles away. The main museum boasts a striking exterior pyramid inspired by the Moche (also called Mochica) sanctuaries, while the exhibits take visitors on a tour as if they were descending into the tombs themselves (see Figure 7 and a video https://www.youtube.com/watch?v=WOYDVbICjio).

\section{Figure 7. Royal Tombs of Sipán Museum, Labayaeque.}
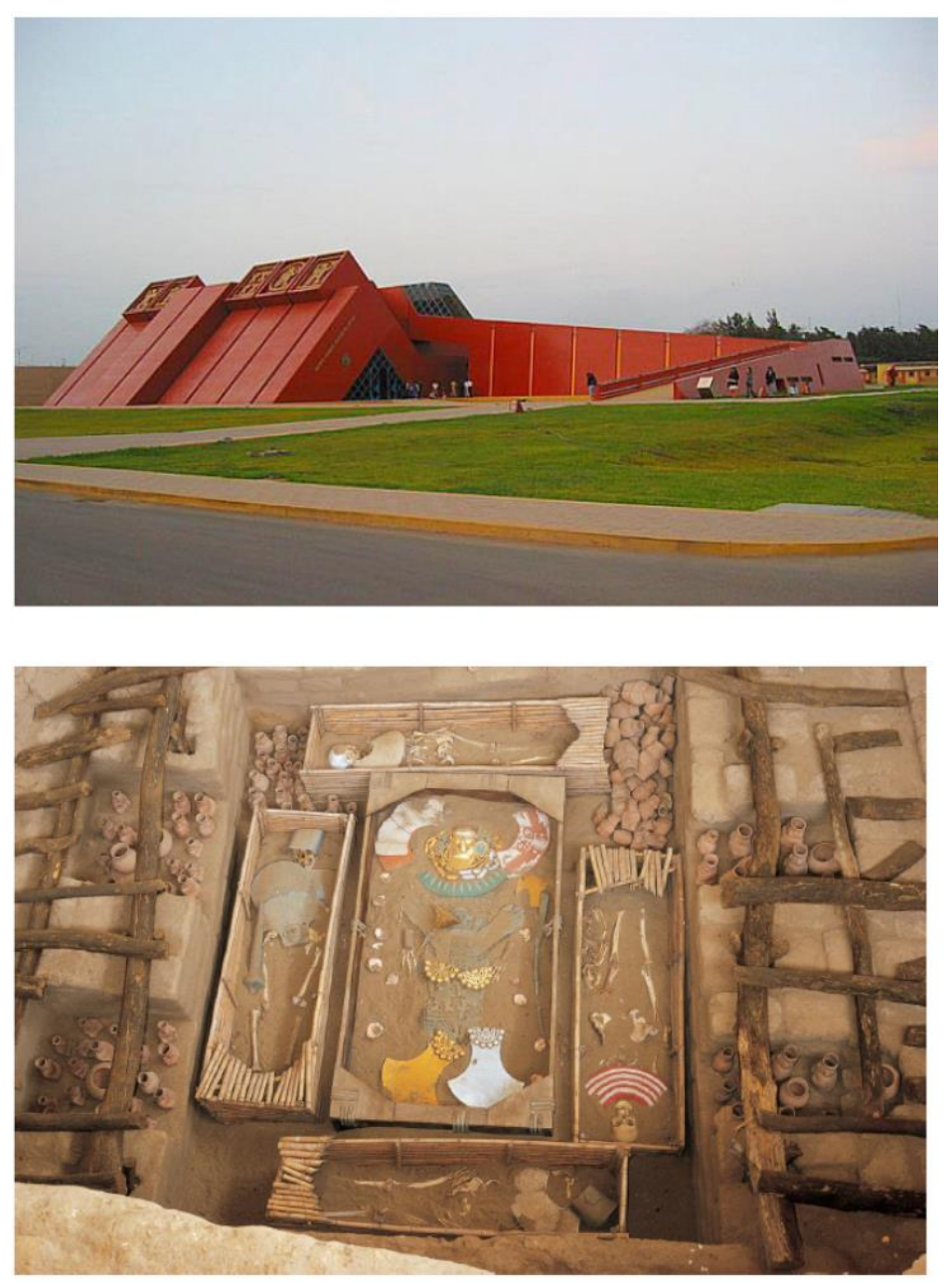


\section{Market and Consumption Policies}

Can the Peruvian antiquities market be governed in such a way as to accommodate collector and commercial interests along with scientific and indigenous cultural heritage interests? No responsible party on either side of the debate wants completely free trade in cultural goods (Merryman 2005). On the other hand, extinguishing the market for the sake of scientific purity seems unlikely as a practical matter. Developing countries often lack the means to protect their cultural heritage from subsistence digging and landowner depredations encouraged by strong demand for antiquities among relatively affluent collectors (Atwood 2004; Borodkin 1995; Flecker 2002; Szopa 2004). Despite years of effort, the overall effectiveness of current national laws and international conventions remains spotty (Szopa 2004). Local patrols have helped and technology may provide some new tools. For instance, in 2013 the Peruvian Ministry of Culture started deploying drones to keep tabs on public heritage sites susceptible to the incursions of developers (Greenwood 2015). Nevertheless, overall enforcement remains porous.

Some analysts recommend trying to control the trade through a more market-based approach. Borodkin (1995), for example, advocated a state auction model for antiquities that might be applied to the Peruvian ceramics. In this approach, governments offer looters a higher price than would smugglers. Looters would be encouraged to provide information about when and where the artifacts were discovered. The more careful the excavation and the better the data provided, the higher the compensation. To finance such a system, duplicates would be sold at public auction. Given the great number of less valuable pieces of pottery, metals, and textiles available, perhaps this model could work in Peru. However, this still encourages looting and the scientific knowledge that could be produced would be questionable.

Ultimately, however, demand needs to be addressed and issues of responsible private and public collecting need to be raised. Collectors should at the very least set voluntary standards in regards to cultural goods. Within the museum community ethical norms appear to have evolved since the 1980s (Felch and Frammolino 2011) and numerous museums have adopted policies that prohibit their acquisition of antiquities that lack provenance before 1970, the date set by the UNESCO Convention (Cuno 2008; Gerstenblith 2007). Major auction houses are also becoming reluctant to accept consignments of important antiquities that cannot pass the UNESCO provenance test (Blumenthal and Mashberg 2012). These policies may begin to shut down the high end of the market, but private collectors and dealers will still buy and sell artifacts 
in the middle and lower price ranges. Dealer associations have established codes of conduct, but they appear to have serious loopholes (Gerstenblith 2007).

Private collectors should become more aware of the problems associated with buying undocumented Peruvian artifacts. Acquisitive urges are powerful, and sometimes induce compulsive behaviors (Belk 1995). When studying the items on eBay, I myself began to sense a desire to buy and possess a piece of Peruvian heritage. My collector's animal spirits were stirring. Yet, I also know from personal experience that knowledge of how antiquities come to market can impart a negative valence to these objects and so deter purchasing. Thus, the buyers of antiquities should be fully aware of the problems of looting and trafficking and make some effort to obtain fuller knowledge of the source of the objects they consider. Dealers and auction houses need to be as forthcoming as possible about provenance and should educate their clients on the need for all parties to take due diligence. Collectors need to be reminded that purchases with documented provenience and undisputable legal ownership are worth more and are easier to sell than undocumented pieces that are hard to contextualize (Borodkin 1995; Fay 2011; Flecker 2002). Antiquities with certification may also be better investments over the long run, both in financial terms and in the satisfactions they provide to their owners.

\section{Conclusion}

Despite encouraging a good deal of serious archaeology that has expanded knowledge, the collectors market for Peruvian antiquities has also destroyed cultural heritage because of the looting it has inspired. This marketing system is very difficult to control in light of strong collector demand, desires for financial gain, weak law enforcement, and sometimes indifferent public policies. Controlling the trafficking of smaller objects is especially problematic since the Internet facilitates sale and the cost of enforcement may be prohibitive. Yet, by repeatedly stressing the issue of lost cultural heritage, by possibly establishing state auction markets, by setting high standards for museums, auctioneers, and dealers, and by making sure that all collectors understand the reality of the market they support, more egregious practices may be curtailed.

Further research on the collecting of Peruvian cultural goods should be expanded to include colonial and republican period art and artifacts from the sixteenth through nineteenth centuries. Often taken from Catholic churches, sacred items include silverwork, icons/figures/sculptures, paintings, bells, and furniture have entered the global collectors market. 
Some antiques of this nature may originally have been privately held and later sold willingly to a dealer, but most Latin American countries have laws requiring export permits for these pieces and such approvals are not often granted (Yates 2015). Cultural information may have been lost during transfers of ownership.

More micro, theoretically informed interpretive research should be undertaken to assess how individual collectors of Peruvian antiquities feel about their purchases and what they know about provenience and provenance. The topic of meaning in possessions has been an important research area within the field of consumer culture theory since the 1980s (Arnould and Thompson 2005). Such research may be challenging since collectors tend to be dispersed geographically and may be hard to identify. Further, they may be hesitant to talk about their activities for fear of alerting authorities and possibly thieves. But if interviews can be arranged and conducted tactfully, the resulting data may suggest means for steering antiquity collectors away from possibly looted artifacts. 


\section{References}

Arnould, Eric J. and Craig J. Thompson (2005), "Consumer Culture Theory (CCT): Twenty Years of Research," Journal of Consumer Research, 31 (March), 868-82. https://doi.org/10.1086/426626

Atwood, Roger (2002), "Stealing History," Mother Jones (May/June), (accessed November 9, 2017), [available at http://www.motherjones.com/politics/2002/05/stealing-history].

Atwood, Roger (2004), Stealing History: Tomb Raiders, Smugglers, and the Looting of the Ancient World. New York: St. Martin's Press.

Belk, Russell W. (1995), Collecting in a Consumer Society. London: Routledge.

Blumenthal, Ralph and Tom Mashberg (2012), "The Curse of the Outcast Artifact," New York Times (June 12), (accessed November 10, 2017), [available at http://www.nytimes.com/2012/07/15/arts/design/antiquity-marketgrapples-with-stricter-guidelines-forgifts.html? $r=2 \&$ pagewanted=1\&ref=ralphblumenthal].

Borodkin, Lisa J. (1995), "The Economics of Antiquities Looting and a Proposed Legal Alternative," Columbia Law Review, 95/2 (March), 377-417. https://doi.org/10.2307/1123233

Brodie, Neil (2002), "Introduction," in Illicit Antiquities: The Theft of Culture and the Extinction of Archaeology," Neil Brodie and Kathryn Walker Tubb, eds. London: Routledge.

Brodie, Neil (2011), "Congenial Bedfellows? The Academy and the Antiquities Trade," Journal of Contemporary Criminal Justice, 27 (4), 408-37. https://doi.org/10.1177/1043986211418885

Brodie, Neil (2015), "The Internet Market in Antiquities," in Countering Illicit Traffic in Cultural Goods: The Global Challenge of Protecting the World's Heritage, France Desmarai, ed. Paris: ICOM, 11-20, (accessed November 9, 2017), [available at https://issuu.com/internationalcouncilofmuseums/docs/book observ atory illicit traffic ve?e=17199299/31993810].

Cook, Noble David (1998), Born to Die: Disease and New World Conquest, 1492-1650. New York: Cambridge University Press.

Cotter, Holland (2012), "Africa's Vulnerable Treasures," International Herald Tribune (August 4-5), 18, 22. 
Cuno, James (2008), Who Owns Antiquity? Museums and the Battle Over Our Ancient Heritage. Princeton, NJ: Princeton University Press.

Davis, Terressa (2006), "Supply and Demand: A Glimpse into the Traffic of Illicit Khmer Antiquities," Culture Without Context 18 (Spring), (accessed November 10, 2017), [available at http://s3-eu-west2.amazonaws.com/wpmedia.outlandish.com/trafficking/2012/07/27 133424/CWC-18.pdf].

Dobyns, Henry F. and Paul L. Doughty (1976), Peru: A Cultural History. New York: Oxford University Press.

Dominguez, Nuño (2013), "Researchers Lament Destruction of Ancient Peruvian Pyramid," Nature (July 9), (accessed November 9, 2017), [available at http://www.nature.com/news/researchers-lamentdestruction-of-ancient-peruvian-pyramid-1.13359].

Donadio, Rachel (2014), "Vision of Home: Repatriated Works Back in Their Countries of Origin," New York Times (April 17), (accessed November 9, 2017), [available at http://www.nytimes.com/2014/04/20/arts/design/repatriated-worksback-in-their-countries-of-origin.html? $\mathrm{r}=0$ ].

Economist (2016), "Returning the Hatchet: Antiquities in Latin America," (March 12), 35.

Fay, Emily (2011), "Virtual Artifacts: eBay, Antiquities, and Authenticity," Journal of Contemporary Criminal Justice, 27 (4), 449-64. https://doi.org/10.1177/1043986211418887

Felch, Jason and Ralph Frammolino (2011), Chasing Aphrodite: The Hunt for Looted Antiquities at the World's Richest Museum. New York: Houghton Mifflin Harcourt.

Flecker, Michael (2002), "The Ethics, Politics, and Realities of Maritime Archaeology in Southeast Asia," The International Journal of Nautical Archaeology, 31 (1), 12-24. https://doi.org/10.1111/j.10959270.2002.tb01397.x

Gänger, Stephanie (2014), Relics of the Past: The Collecting and Study of Pre-Columbian Antiquities in Peru and Chile, 1837-1911. Oxford, UK: Oxford University Press.

Geismar, Haidy (2001), "What's in a Price? An Ethnography of Tribal Art at Auction," Journal of Material Culture, 6 (1), 25-47. https://doi.org/10.1177/135918350100600102 
Gero, Joan M. (1997), "Royal Tombs of Sipán," American Anthropologist, 97 (2), 353-55.

Gerstenblith, Patty (2007), "Controlling the International Market in Antiquities: Reducing the Harm, Preserving the Past," Chicago Journal of International Law, 8/1 (Summer), 169-95.

Greenwood, Faine (2015), "Guarding Machu Picchu: How Peru Is Using Drones to Protect Its Archaeological Heritage," Slate, (August 24), (accessed November 9, 2017), [available at http://www.slate.com/articles/technology/future tense/2015/08/how peru is using drones to protect machu picchu and other arch aeological.html ].

Heaney, Christopher (2011), Cradle of Gold: The Story of Hiram Bingham, A Real-Life Indiana Jones, and the Search for Machu Picchu. New York: Palgrave Macmillan.

Hunt, Shelby D. (1981), "Macromarketing as a Multidimensional Concept," Journal of Macromarketing, 1 (1), 7. https://doi.org/10.1177/027614678100100103

Layton, Roger A. (2007), "Marketing Systems: A Core Macromarketing Concept," Journal of Macromarketing, 27 (3), 227-42. https://doi.org/10.1177/0276146707302836

Layton, Roger A. (2015), "Formation, Growth, and Adaptive Change in Marketing Systems," Journal of Macromarketing, 35 (3), 302-19. https://doi.org/10.1177/0276146714550314

Lubow, Arthur (2007), "The Possessed," The New York Times Magazine (June 24), (accessed November 10, 2017), [available at http://www.nytimes.com/2007/06/24/magazine/24MachuPicchut.html?pagewanted=all].

Mann, Charles C. (2005), 1491: New Revelations of the Americas Before Columbus. New York: Vintage Books.

Merryman, John Henry (1986), "Two Ways of Thinking about Cultural Property," The American Journal of International Law, 80 (4) (October), 831-53. https://doi.org/10.2307/2202065

Merryman, John Henry (2005), "Cultural Property Internationalism," International Journal of Cultural Property, 12, 11-39. https://doi.org/10.1017/S0940739105050046 
Miller, George L. (1992), "The Second Destruction of the Geldermalsen," Historical Archaeology, $26 \quad$ (4), 124-31. https://doi.org/10.1007/BF03374521

Myers, Steven Lee (2010), "Iraq's Ancient Ruins Face New Looting," The New York Times, (June 25), (accessed November 10, 2017), [available

at http://www.nytimes.com/2010/06/26/world/middleeast/26looting.htm !].

OAS (2017), "Multilateral Treaties," Department of International Law, Organization of American States, Washington, D.C., (accessed August 2, 2017), [available at http://www.oas.org/juridico/english/treaties/c-16.html].

Peters, Gretchen (2009), "More Than 1500 Stolen Afghan Artifacts Return to Kabul," National Geographic News (March 6), (accessed November 10, 2017), [available at http://news.nationalgeographic.com/news/2009/03/090306afghanistan-artifacts-returned-missions.html].

Pollan, Michael (2002), The Botany of Desire: A Plant's-Eye View of the World, New York: Random House.

Pope, Frank (2007), Dragon Sea: A True Tale of Treasure, Archaeology, and Greed off the Coast of Vietnam. Orlando, FL: Harcourt, Inc.

Szopa, Alia (2004), "Hoarding History: A Survey of Antiquity Looting and Black Market Trade," University of Miami Business Law Review, (Fall/Winter), 13-55.

UNESCO (2017), Convention on the Means of Prohibiting and Preventing the Illicit Import, Export and Transfer of Ownership of Cultural Property 1970, (accessed August 2, 2017), [available at http://portal.unesco.org/en/ev.php-

URL ID=13039\&URL DO=DO TOPIC\&URL SECTION=201.html].

Yates, Donna (2012), "Huaquero," Trafficking Culture: Researching the Global Traffic in Looted Cultural Objects, (August 7), (accessed November 9, 2017), [available at http://traffickingculture.org/encyclopedia/terminology/huaquero-2/].

Yates, Donna (2014), "Dos Cabeza," Trafficking Culture: Researching the Global Traffic in Looted Cultural Objects, (March 5), (accessed November

9 , 2017), [available at 
http://traffickingculture.org/encyclopedia/case-studies/doscabezas/].

Yates, Donna (2015), "Illicit Cultural Property from Latin America: Looting, Trafficking, and Sale," in Countering Illicit Traffic in Cultural Goods: The Global Challenge of Protecting the World's Heritage, France Desmarai, ed. Paris: ICOM, 33-46, (accessed November 10, 2017), [available https://issuu.com/internationalcouncilofmuseums/docs/book observ atory illicit traffic ve?e=17199299/31993810 ] 